Piotr KOLMANN

Szkoła Gtówna Stużby Pożarniczej w Warszawie ${ }^{1}$

Wydzial Inżynierii Bezpieczeństwa i Ochrony Ludności

pkolmann@sgsp.edu.pl

ORCID 0000-0001-9857-9353

https://doi.org/10.34739/dsd.2020.01.05

\title{
Z PROBLEMATYKI OCHRONY LUDNOŚCI. ISTOTA EWAKUACJI W UJECCIU POWSZECHNYM
}

\begin{abstract}
ABSTRAKT: Pojęcie ewakuacji jest od wieków w powszechnym użytku, zarówno w mowie potocznej, jak i w ramach ustaleń czy regulacji odnoszących się do zapewniania szeroko rozumianej ochrony ludności. W artykule przedstawiono wyniki dokonanego przeglądu źródeł bibliograficznych pod kątem identyfikacji natury i istoty zjawiska ewakuacji. Wobec zidentyfikowania różnorodnych ujęć (w tym ogólnego i specjalistycznego), po dokonaniu ich usystematyzowania $\mathrm{i}$ analizy $\mathrm{w}$ ramach studium komparatystycznego, przedstawionego na gruncie dwóch powiązanych ze sobą artykułów, zaproponowano autorską definicję ewakuacji.
\end{abstract}

SŁOWA KLUCZOWE: nauki o bezpieczeństwie, ochrona ludności, ewakuacja, terminologia

\section{FROM CIVIL PROTECTION ISSUES. THE IMPORTANCE OF EVACUATION IN THE GENERAL PERSPECTIVE}

\begin{abstract}
The concept of evacuation has been widely used for centuries, both in colloquial speech and as part of arrangements and regulations relating to ensuring widely understood civil protection. The article presents the results of the review of bibliographic sources for purpose of identifying the nature and essence of the phenomenon of evacuation. Due to the identification of various approaches (including general and specialist), after systematizing and analyzing them within the framework of comparative studies, presented on the basis of two related articles, the author's definition of evacuation was proposed.
\end{abstract}

KEYWORDS: security studies, civil protection, evacuation, terminology

\section{WPROWADZENIE}

Celem niniejszego artykułu jest przedstawienie wyników dokonanego przeglądu źródeł bibliograficznych - stanowiących w szczególności słowniki języka polskiego oraz słowniki wyrazów obcych - pod kątem identyfikacji natury takiego ważnego zjawiska właściwego ochronie ludności jak ewakuacja. Problematyka ta jest naturalnie mocno skorelowana

\footnotetext{
${ }^{1}$ The Main School of Fire Service in Warsaw, Poland.
} 
z nadrzędnym bezpieczeństwem powszechnym, a szerzej także narodowym. Nie jest przy tym nader często podejmowana $\mathrm{w}$ rozważaniach badawczych $\mathrm{w}$ ramach nauk o bezpieczeństwie.

Liczne egzemplifikacje realizacji procesów właściwych ewakuacji stanowią potwierdzenie istotności podjętej problematyki, która to odnajduje również swoje odzwierciedlenie nie tylko w pozycjach słownikowych, lecz także w licznych przepisach prawa powszechnie obowiązującego, dokumentach normalizacyjnych, regulacjach wewnątrzorganizacyjnych czy specjalistycznej literaturze przedmiotu. Biorąc pod uwagę zagrożenia współczesnego świata, z uwzględnieniem losowych, nieprobabilistycznych bądź z innych względów trudnych w prognozowaniu licznych zagrożeń naturalnych i cywilizacyjnych, znaczenie prowadzenia ewakuacji jest stawiane w świetle podstawowej aktywności ratowniczej bądź prewencyjnej podejmowanej zarówno przez każdego człowieka, jak i dedykowane temu organizacje bezpieczeństwa.

Nie jest niczym zaskakującym, że zagadnienia właściwe ewakuacji (w tym terminologiczne) stały się przedmiotem (potencjalnej) regulacji czynionej nie tylko na łamach słowników, lecz także ustaw, rozporządzeń, zarządzeń, wytycznych, regulaminów, planów, instrukcji, zaleceń, norm itp. Dokonanie przeglądu słowników języka polskiego oraz słowników wyrazów obcych pod kątem występowania w nich definicji ewakuacji stanowi podstawowy cel przyświecający niniejszemu artykułowi. W zakresie artykułu dokonano usystematyzowania zidentyfikowanych ujęć, celem poddania ich analizie i krytyce w ramach studium komparatystycznego. Dalsze studia przeglądowe, uwzględniające w szczególności przepisy prawa, normy techniczne czy słowniki terminów specjalistycznych, będą stanowić drugą część z rozważań autora ujętą w kolejne opracowanie artykułowe. Będzie ono zawierać ponadto zwieńczenie przedsięwziętego wysiłku badawczego $\mathrm{w}$ postaci zaproponowania własnej definicji ewakuacji.

Wiodącą przesłanką podjęcia się przez autora tytułowego tematu jest obserwowana mnogość ujęć występująca w dokumentach źródłowych, które posługują się terminem ewakuacji nierzadko bez jego szczególnego zdefiniowania bądź zawierają zróżnicowane, niezgodne czy wykluczające się ujęcia definicyjne. Mimo niejako wspólnego trzonu powszechnie ukonstytuowanego traktowania i zastosowania pojęcia ewakuacji, związanego z jego pochodzeniem etymologicznym, występują liczne zaakcentowania cech pobocznych tejże aktywności - przejawiającej się w przypadku realnego lub potencjalnego stanu zagrożenia. Należy w szczególności wskazać na występującą różnorodność podmiotową oraz przedmiotową, czy same charakter i skalę działań podejmowanych w realizacji procesów ewakuacji. Tym samym autor $\mathrm{w}$ optyce niniejszego artykułu pragnie pochylić się nad problemem badawczym sformułowanym jako: czym współcześnie jest ewakuacja? Zarazem zostanie on podtrzymany w rozważaniach na potrzeby kolejnego opracowania ${ }^{2}$.

\footnotetext{
${ }^{2}$ Artykuł ten będzie dotyczyć poznania istoty ewakuacji traktowanej w ujęciu specjalistycznym, w którym to jednocześnie zostanie przedstawiona i zaproponowana autorska definicja ewakuacji.
} 
Celem realizacji procesu poznania naukowego posłużono się metodą analizy i krytyki piśmiennictwa, przy czym wyniki uzyskane w ramach przeprowadzonych dociekań mają charakter wstępny.

\section{ZARYS ETYMOLOGICZNY WLAŚCIWY POJECCIU EWAKUACJI}

Rozpoczynając swoje rozważania autor w pierwszej kolejności sięgnął do wybranych słowników wyrazów obcych oraz słowników języka polskiego. Już wyniki pobieżnie dokonanej ich analizy pozwalają stwierdzić, że nie zawierają one w pełni spójnego ze sobą stanowiska $\mathrm{w}$ interesujących autora sprawach. W ujęciach licznie tam prezentowanych wskazano bowiem na szereg występujących definicji podjętego w koncypowanie terminu ewakuacji, przy czym nierzadko można się doszukać w ich ramach pewnych cech wspólnych, istotnych ze względu na podjęty problem badawczy.

W świetle poszukiwań pierwotnego znaczenia pojęcia, zazwyczaj nadal rzutującego na współczesne jego rozumienie, należy zwrócić się do osiągnięć na gruncie etymologicznym. Zenon Klemensiewicz określił, że zadaniem etymologii jest „ustalić pochodzenie, czas i sposób powstania wyrazu, podać uzasadnienie jego pierwotnej budowy głoskowej, słowotwórczej i najstarszego znaczenia oraz wskazać kolejne zmiany znaczeniowe, objaśnione różnymi czynnikami, które kształtowały historyczny byt danej społeczności językowej"3. Autor z racji uprawianej dyscypliny naukowej odmiennej językoznawstwu nie będzie przedstawiał pełnoprawnego wywodu etymologicznego, jednakże informacje dostępne w licznych źródłach słownikowych zdają się układać w ciąg logiczny i nie zawierają kategorycznych rozbieżności czy sprzeczności. Ustalenie historyczno-etymologicznych powiazań nie jest zadaniem łatwym, jednakże w świetle rozważań niniejszego artykułu wyraźnie widać, jak zależności znaczeniowe ewakuacji kształtowały się na przestrzeni biegu wieków. Co więcej, po dodatkowym uwzględnieniu ujęć specjalistycznych ${ }^{4}$, autor proponując szerokie ujęcie również planuje mieć w to swój skromny wkład.

Dociekając zagadnień etymologicznych właściwych ewakuacji należy podkreślić, że jego pochodzenia należy doszukiwać się przede wszystkim z późnołacińskiego evacuatio, oznaczającego opróżnienie ${ }^{5}$ znikanie $^{6}$ - od łacińskiego evacuare, oznaczającego opróżniać ${ }^{7}$,

\footnotetext{
${ }^{3}$ A. Brückner, Stownik etymologiczny języka polskiego, Warszawa 1985, s. 5.

${ }^{4}$ Vide P. Kolmann, Z problematyki ochrony ludności. Istota ewakuacji w ujęciu specjalistycznym, kps dostępny u autora, Warszawa 2020, artykuł złożony do kolejnego numeru czasopisma „De Securitate et Defensione. O Bezpieczeństwie i Obronności”.

${ }^{5}$ Stownik wyrazów obcych. 17.000 wyrazów, Z. Rysiewicz (red.), Warszawa 1961, s. 202; Wielki słownik języka polskiego, P. Żmigrodzki (red.), Kraków 2007-, hasło: ewakuacja, dostępny w Internecie: http://www.wsjp.pl/index.php?id_hasla=28351; vide także Stownik wyrazów obcych, I. Kamińska-Szmaj (red.), Wrocław 2001, s. 212 - z różnicą w adnotacji etymologicznej wskazującej na pochodzenie nowołacińskie. Na (późno)łaciński źródłosłów wskazują także niektóre inne słowniki, przy czym pozycje te nie zawierają szerszych informacji etymologicznych, tj. obszerniejszych aniżeli sam język pochodzenia podjętego w rozważania pojęcia.

${ }^{6}$ Dodatkowo wskazane obok „opróżnianie”, z nakreśleniem powstania łacińskiego słowa evacuatio od e-, ex- przedrostek: z czegoś, vacuus - pusty. A. Caba et al., Wielki słownik wyrazów obcych, Kraków 2008, s. 267. Znaczenie łacińskiego ,wakuje” z rodzaju nijakiego od vacuus również jest podawane jako ,próżny; bezludny;
} 
znikać $^{8}$, a we współczesnym ujęciu tyle co ewakuować. Także w Wielkim słowniku wyrazów obcych $i$ trudnych wskazano na francuskie évacuation $\mathrm{z}$ późnołacińskiego evacuatio opróżnienie ${ }^{9}$. Niektóre ze słowników odsyłają z kolei wprost jedynie do późniejszego wspomnianego już francuskiego słowa évacuation ${ }^{10}$, nie odnosząc się szerzej do zagadnień etymologicznych. Na stronach Wielkiego słownika języka polskiego jednocześnie wskazano ponadto $\mathrm{w}$ kontekście pochodzenia kreślonego słowa na angielskie evacuation ${ }^{11}$. Mając na względzie zawarte ustalenia, w wielu innych językach analizowany termin funkcjonuje w zbliżonej formie, co nakreśla jego wspólny rodowód - niem. Evakuation, ros. эвакуация (évakuaciâ), hiszp. evacuación, czes. evakuace, esper. evakuado i liczne dalsze ${ }^{12}$.

\section{ZARYS ZNACZENIOWY EWAKUACJI W UJECIU POWSZECHNYM}

Powszechne w dostępie słowniki odnoszące się do języka polskiego oraz wyrazów obcych stanowią źródło terminów powszechnie znanych i stosowanych w mowie czy piśmie. Niektóre starsze pozycje słownikowe języka (staro)polskiego czy etymologiczne, do których udało się autorowi dotrzeć zdają się nie uwzględniać terminu ewakuacji ${ }^{13}$. Mając to na względzie, trudno jest oszacować bliższy czas, w którym z dużym prawdopodobieństwem analizowane pojęcie mogło pojawić się w języku polskim, a także w jakiej dokładnie formie, o jakiej genezie czy o jakim pierwotnym znaczeniu. Najwcześniejsze poświadczenie wskazuje na rok $1763^{14}$ „Województwa Wielkopolskie wysłały Posłów do Króla prosząc o ewakuacyą Sasów, á życząc zgody z Szwedami, jakoż w krótce Saśi wyszli z granic Polskich" ${ }^{15}$. Zatem w języku polskim termin ten jest już obecny od co najmniej ponad 250 lat.

W pięciu z najstarszych zidentyfikowanych pozycji je zawierających można doszukać się definicji, które w mniemaniu autora zdają się nie do końca w pełni oddawać istotę współcześnie traktowanej ewakuacji, będąc nakierowanymi na znaczenia już archaiczne bądź ograniczone podmiotowo lub przedmiotowo. Wobec krótkiej myśli zawartej w Słowniku

\footnotetext{
bez zajęcia”. Stownik wyrazów obcych i zwrotów obcojęzycznych, W. Kopaliński (red.), Warszawa 1967, s. 793; vide także hasło EKS-.

${ }^{7}$ Cf. Z. Rysiewicz (red.), op. cit., s. 202; W. Kopaliński (red.), op. cit., s. 229.

${ }^{8}$ Dodatkowo wskazane obok „opróżniać”, z nakreśleniem powstania łacińskiego słowa evacuare analogicznie, jak wyżej, tj. od e-, ex-- przedrostek: z czegoś, vacuus - pusty. A. Caba et al., op. cit., s. 267.

${ }^{9}$ A. Markowski, R. Pawelec, Wielki stownik wyrazów obcych i trudnych, Warszawa 2001, s. 225.

${ }^{10}$ Vide: Uniwersalny stownik języka polskiego. Tom 1. A-J, S. Dubisz (red.), Warszawa 2003, s. 863; Wielki stownik wyrazów obcych PWN, M. Bańko (red.), Warszawa 2005, s. 366.

${ }^{11}$ P. Żmigrodzki (red.), op. cit., hasło: ewakuacja.

${ }^{12}$ Hasło ewakuacja jest skojarzone naturalnie z odpowiednikami i w dalszych językach, gdzie jego pisownia w licznych przypadkach także wyraźnie wskazuje na pokrewieństwo z opisanym w niniejszym artykule łacińskim protoplastą omawianego terminu.

${ }^{13}$ Cf. A. Krasnowolski, W. Niedźwiedzki (oprac.), M. Arcta. Stownik staropolski. 26,000 wyrazów i wyrażeń użyanych w dawnej mowie polskiej, Warszawa 1916; A. Brückner, Stownik etymologiczny języka polskiego, Kraków 1927; Stownik polszczyzny XVI wieku, Tom 6. DRA-EŻBY, M. Borecki (red. tomu), Wrocław 1972.

14 Elektroniczny stownik języka polskiego XVII i XVIII wieku, W. Gruszczyński (red.), Warszawa 1954, http://sxvii.pl/index.php?strona=haslo\&id_hasla=45038\&forma=EWAKUACJA (31.01.2020), hasło ewakuacja (zalążek artykułu hasłowego).

${ }^{15}$ W.A. Lubieński, Historya Polska. Z opisaniem Rządu i Urzędów Polskich, Wilno 1763, s. 123.
} 
Lidego, zgodnie z ówczesną pisownią, ewakuacya to „wypróżnienie, rugowanie” ${ }^{16}$. W Stowniku wileńskim termin ten występuje już we współczesnej pisowni, ze wskazaniem na łacińskie pochodzenie, i zgodnie z zawartą definicją oznacza „wypróżnienie, oczyszczenie, ustąpienie"17. Według opublikowanych tamże ustaleń ewakuować to tyle co „wypróżniać, oczyszczać; wyprowadzać wojska z jakiego miejsca"18. W Słowniku warszawskim, ze wskazaniem na przytaczane już pochodzenie od łacińskiego (tym razem nie późnołacińskiego) evaciuatio, ewakuacją jest w pierwszym znaczeniu „opróżnienie”, w drugim „rugowanie, usunięcie”, a w trzecim z adnotacją wojskowy „opróżnienie szpitali z rannych i chorych"19. Ewakuować to „opróżniać, rugować, wyprowadzać skąd, np. wojsko” ${ }^{20}$. W dwóch uwzględnionych pozycjach słownikowych schyłku dwudziestolecia międzywojennego położono zdecydowanie mocniejsze akcenty kierujące uwagę czytelnika ku wojskowości, w myśl definicji tam zawartych ewakuacja bowiem została zdefiniowana odpowiednio jako „ustąpienie, opuszczenie warowni lub kraju przez wojska; opróżnienie szpitala $\mathrm{z}$ chorych”21 oraz „opróżnienie miejscowości lub okolicy z zapasów żywności, amunicji, szpitalów, zakładów wojskowych, ludności cywilnej”22, gdzie ludność została wymieniona w zasadzie dopiero na ostatnim miejscu.

Nieco szersze, lecz nadal podobnie zabarwione wojskowością podejście przedstawiono w Słowniku wyrazów obcych pod redakcją Zygmunta Rysiewicza. Według tam zamieszczonego ujęcia ewakuacją jest „wywożenie ludności, przedsiębiorstw, instytucji z okolic zagrożonych przez najazd nieprzyjaciela, po jakiejś klęsce żywiołowej (w celu udzielenia pomocy ludności jej dotkniętej) lub w wypadku, gdy na danym terenie planuje się jaką́s wielką budowę państwową; planowe wywożenie rannych, chorych, mienia wojskowego z terenu działań wojennych"23. W kontekście planowania wymienianej tam wielkiej budowy państwowej bardziej adekwatne zdaniem autora byłoby użycie kategorii przesiedlenia, wysiedlenia. Dalej, odnośnie wskazanego wywożenia rannych i dalszych określenie jedynie planowego charakteru zdaje się niewystarczające (wymiar prewencyjny), pod naporem walk bowiem może być to także czynione w sposób doraźny, aczkolwiek w ramach możliwości zgodnie z planami, o ile są adekwatne do sytuacji. Pojawia się tym samym nie tylko skupienie na problemie wojny, lecz także wyraźne odniesienie się zarazem do innych uwarunkowań prowadzących do przeprowadzenia ewakuacji klęski żywiołowej, co licznie zaprezentowano także w kolejnych ze słownikach.

W Słowniku języka polskiego pod redakcją Witolda Doroszewskiego wskazano na dwa znaczenia analizowanego w ramach artykułu terminu. W pierwszym to „usuwanie ludności cywilnej lub wojska, wywożenie majątku $\mathrm{z}$ terenów zagrożonych przez nieprzyjaciela

\footnotetext{
${ }^{16}$ S.B. Linde, Stownik języka polskiego. Tom 1. A-F, Lwów 1854, s. 632.

${ }_{17}$ A. Zdanowicz et al., Stownik języka polskiego. Tom 1. A-O, Wilno 1861, s. 302.

18 Ibidem.

${ }^{19}$ Słownik języka polskiego. Tom 1. A-G, J. Karłowicz, A. Kryński, W. Niedźwiedzki (red.), Warszawa 1900, s. 705.

${ }^{20}$ Ibidem.

${ }^{21}$ H. Ułaszyn (cz. oprac.), M. Arcta. Słownik wyrazów obcych. 33.000 wyrazów, wyrażeń $i$ przystów cudzoziemskich, Warszawa 1937, s. 78.

${ }^{22}$ Trzaski, Everta i Michalskiego. Encyklopedyczny słownik wyrazów obcych. Pochodzenie wyrazów, wymowa, objaśnienia pojęć, skróty, przysłowia cytaty, S. Lam (red.), Warszawa 1939, s. 206, k. 529.

${ }^{23}$ Z. Rysiewicz (red.), op. cit., s. 202.
} 
w czasie działań wojennych lub nawiedzonych klęską żywiołową", w drugim z kolei „opróżnianie terenu, budynku itp.” ${ }^{24}$, w którym to pominięto jednak czynnik zagrożenia (czy tym samym, np. przeprowadzkę można określić mianem ewakuacji?). Pojawia się również termin ewakuant, czyli „ten, kto został ewakuowany, kto ewakuował się" ${ }^{25}$. Nieco szersze, lecz nadal podobnie zabarwione m.in. wojskowością podejście przedstawiono w Słowniku wyrazów obcych $i$ zwrotów obcojęzycznych pod redakcją Władysława Kopalińskiego, gdzie ewakuacja to „usuwanie, wywożenie ludności, instytucji, majątku, dobytku itd. z terenów zagrożonych przez nieprzyjaciela (w czasie wojny) a. nawiedzonych klęską żywiołową"26. Wskazano, że ewakuacja jest przeprowadzana $\mathrm{z}$ terenów zagrożonych przez nieprzyjaciela (w czasie wojny) albo nawiedzonych klęską żywiołową, przy czym jest to nadal zbyt wąskie podejście w świetle tego, że konieczność dokonania ewakuacji może być spowodowana występowaniem co do zasady jakiegokolwiek zagrożenia związanego z nieakceptowalnym poziomem ryzyka. Dopiero w kolejnych słownikach widać uwzględnianie szerokich ujęć możliwych katalogów zagrożeń, mimo to pośród licznych nadal widać utrwalone podeście do zawężania ich zaledwie do zagrożeń wojennych i klęsk żywiołowych.

Słownik współczesnego języka polskiego pod redakcją Bogusława Dunaja wskazuje na jednoznaczne powiązanie pojęcia ewakuacji z terenem zagrożenia, nakreślając, że ewakuacją jest „usuwanie, wywożenie ludności cywilnej lub wojska, majątku ruchomego, sprzętu itp. $\mathrm{Z}$ terenu zagrożenia (np. w czasie wojny lub klęski żywiołowej, poważnej awarii itp.)"27. Pojawia się tutaj jednak już wyraźnie odnotowana w przywołanym wyliczeniu przykładów kwestia nie tylko czasu wojny czy klęski żywiołowej, lecz także poważnej awarii - trafnie sprowadzonych do terenu zagrożenia, z którego to ewakuacja nakreślonego katalogu podmiotów (niepełnego) ma się odbywać. Już w świetle powyższego zbyt wąskie ujęcie zostało przedstawione natomiast na gruncie Wielkiego słownika wyrazów obcych, w myśl którego ewakuacją jest „wywożenie ludzi, dobytku itp. z terenów zagrożonych przez nieprzyjaciela lub żywioł (np. powódź)"28. Potwierdza to powszechność wąskiej propozycji, która jest nadal obecna w nowo wydawanych słownikach - pytaniem otwartym pozostaje, czy zasadnie?

Podkreślić należy, że ewakuacja jest prowadzona we wszystkich stanach funkcjonowania państwa (pokoju czy nadzwyczajnych, w tym wojny), a także przy zdarzeniach wymagających różnego stopnia angażowania sił i środków organizacji bezpieczeństwa - od zdarzeń rutynowych po zdarzenia kryzysowe. Wiele sytuacji wymaga przeprowadzania ewakuacji, w ramach której można ewakuować, czyli „dokonywać, dokonać ewakuacji" ${ }^{29}$, szeroki i w zasadzie otwarty katalog wytypowanych podmiotów podlegających temu procesowi. Ewakuacyjny to w końcu „dotyczący ewakuacji, mający na celu ewakuację,

\footnotetext{
24 Stownik języka polskiego. Tom 2. D-G, W. Doroszewski (red.), Warszawa 1960, s. 772.

${ }^{25}$ Ibidem.

${ }^{26}$ W. Kopaliński (red.), op. cit., s. 229.

27 Słownik współczesnego języka polskiego, B. Dunaj (red.), Warszawa 1996, s. 243.

${ }^{28}$ A. Caba et al., op. cit., s. 267.

${ }^{29}$ B. Dunaj (red.), op. cit., s. 243.
} 
umożliwiający ewakuację"30, np. wyjście ewakuacyjne, droga ewakuacyjna, oświetlenie ewakuacyjne, plan ewakuacyjny.

Ogólniejsze podejście widoczne jest natomiast na gruncie Wielkiego słownika wyrazów obcych $i$ trudnych, gdzie ewakuacja to ,usunięcie ludności, zwierząt, majątku z zagrożonego czymś miejsca, np. z zagrożonych terenów w czasie działań wojennych lub klęski żywiołowej”31. Nakreślono tym samym szeroki, półotwarty katalog podmiotów podlegających ewakuacji, a także pozostawiono otwartym katalog zagrożeń mogących do tego doprowadzić. Nie odniesiono się jednak do tego, że przemieszczenia należy dokonać w miejsce bezpieczniejsze aniżeli pierwotne bądź najlepiej powszechnie uznane za bezpieczne. Ewakuować to z kolei „usuwać ludzi, zwierzęta lub majątek z zagrożonych miejsc"32, a ewakuacyjny to po prostu ,związany z ewakuacją, służący do ewakuacji" ${ }^{33}$. Węższe podejście, aczkolwiek uwzględniające bezpieczeństwo docelowego miejsca rozmieszczenia w ramach ewakuacji, prezentowane jest w kolejnym z uwzględnionych słowników wyrazów obcych, gdzie ewakuacją jest „przewożenie, przenoszenie ludzi, sprzętu z terenów zagrożonych działaniami wojennymi lub klęską żywiołową w oddalone, bezpieczne miejsca"34. W szczególności wskazano tu na oddalone, bezpieczne miejsca, przy czym w praktyce nie muszą być one dalece oddalone, co zależy od wielu czynników. Jest to aktualne w szczególności wtedy, gdy strefa zagrożenia jest o stosunkowo niewielkim obszarze (np. determinowana zagrożeniem punktowym) i nie ma ryzyka jej rozszerzenia się czy przemieszczenia się źródła zagrożenia, co jest przedmiotem szerszych rozważań w ramach ujęcia specjalistycznego ewakuacji.

W pierwszym znaczeniu podanym w Uniwersalnym słowniku języka polskiego $\mathrm{z}$ adnotacjami wojskowość, wojskowy oraz urzędowy - ewakuacja to „wywiezienie, wywożenie ludności cywilnej lub wojska, majątku, dobytku itp., likwidacja zakładów, urzędów z terenów zagrożonych przez nieprzyjaciela lub nawiedzonych klęską żywiołową"35. Ujęcie to jest zbyt wąskie w świetle możliwych wariantów, w tym licznie poprzedzających. W drugim z kolei znaczeniu $\mathrm{z}$ adnotacjami potoczny, potocznie oraz żartobliwy, żartobliwie rozpatrywane pojęcie zdefiniowane zostało ogólnie jako „opuszczenie, opuszczanie jakiegoś miejsca” ${ }^{36}$. Co warte odnotowania, w słowniku tym pojawia się też już raz przywołany termin ewakuant, który w znaczeniu z adnotacją przestarzały oznacza tyle co „osoba, która została ewakuowana lub która się ewakuowała"37. Dalej, z adnotacjami wojskowość, wojskowy oraz urzędowy ewakuować to „przeprowadzić, przeprowadzać ewakuację" ${ }^{38}$. W pierwszym znaczeniu $\mathrm{z}$ adnotacjami wojskowość, wojskowy oraz urzędowy ewakuować się to „opuścić, opuszczać tereny zagrożone

\footnotetext{
${ }^{30}$ Ibidem.

${ }^{31}$ A. Markowski, R. Pawelec, op. cit., s. 225.

${ }^{32}$ Ibidem.

${ }^{33}$ Ibidem.

${ }^{34}$ I. Kamińska-Szmaj (red.), op. cit., s. 212.

${ }^{35}$ S. Dubisz (red.), op. cit., s. 863.

${ }^{36}$ Ibidem.

${ }^{37}$ Ibidem, s. 864

${ }^{38}$ Ibidem.
} 
przez nieprzyjaciela lub nawiedzone klęską żywiołową", w drugim natomiast z adnotacjami potoczny, potocznie oraz żartobliwy, żartobliwie „opuścić, opuszczać jakieś miejsce, pomieszczenie; wyjść, wychodzić" ${ }^{39}$.

Z kolei w nieco młodszej pozycji tego samego wydawcy - Wielkim słowniku wyrazów obcych $P W N$ - ewakuacja to już w pierwszym znaczeniu ,wywożenie ludzi, zwierząt i dobytku $\mathrm{z}$ terenów zagrożonych wojną lub nawiedzonych klęską żywiołową" ${ }^{40}$, oraz o drugim z adnotacją żartobliwy, żartobliwie „opuszczenie jakiegoś miejsca, pomieszczenia"41, wskazującym tym samym krótko, jak ewakuacja może być rozumiana w powszechnym, potocznym mniemaniu. Ujęcie potoczne ewakuacji wcale nie musi być więc logicznie powiązane z zagrożeniem, przy czym niejednokrotnie sam ewakuant może tutaj dopisać obecność zagrożenia odnoszącego się do jego subiektywnego, autokratycznie wyznaczanego wymiaru bezpieczeństwa personalnego.

W opinii autora, w pierwszym znaczeniu właściwym naukom o bezpieczeństwie przywołana powyżej definicja jest nadal nazbyt szczegółowa (wąska), nie obejmuje sobą bowiem całości zjawiska. Wywożenie błędnie sugeruje konieczność zastosowania środka transportu do realizacji tegoż celu, gdyż ewakuacja może odbywać się także bez wykorzystania żadnego, tj. odbyć się w szczególności pieszo, o własnych siłach samych podlegających ewakuacji bądź z pomocą innych osób (wyprowadzenie, wyniesienie). Katalog ewakuantów został zdaniem autora relatywnie dobrze odzwierciedlony i uogólniony, jednak przy niepotrzebnym zawężeniu perspektywy rozpatrywania sfery zagrożeń mogących generować potrzebę przeprowadzenia ewakuacji. Ponadto trafniejszym zdaje się być posłużenie się po prostu określeniem „ludzi, pozostałych istot żyjących i rzeczy” zamiast wskazanie na nieco węży katalog podmiotów w postaci tamże obecnych ludzi, zwierząt i dobytku. Podobnie zastąpienie ,z terenów zagrożonych wojną lub nawiedzonych klęską żywiołową" na ogólniejsze „,z miejsc zagrożonych lub potencjalnie zagrożonych” zdaje się właściwsze wobec szerokiego katalogu współczesnych zagrożeń. Kolejną możliwością jest odniesienie się po prostu do stanu zagrożenia bądź potencjalnego zagrożenia.

Ostatni już z uwzględnionych słowników - Wielki słownik języka polskiego - podobnie jak część licznie poprzedzających pozycji nakreśla także dwa znaczenia obranego w rozważania pojęcia, z czego drugie też zostało opatrzone adnotacjami ,potoczne” oraz „żartobliwe”. W pierwszym ewakuacją jest jednak ,zorganizowane wyprowadzenie ludzi bądź zwierząt z miejsca, w którym grozi im niebezpieczeństwo" 42 , gdzie widać nacisk na zorganizowanie (w domyśle przez uprawnione i zobligowane do tego organizacje bezpieczeństwa), choć nie musi ono odgrywać kluczowej roli chociażby w licznych przypadkach ewakuacji prowadzonych w sposób samorzutny, doraźny, pilny, nieplanowy, niekontrolowany, nienadzorowany. Z kolei wyprowadzenie sugeruje raczej niewielki zasięg, tym samym miejsce bezpieczne musiałoby

\footnotetext{
${ }^{39}$ Ibidem.

${ }^{40}$ M. Bańko (red.), op. cit., s. 366.

${ }^{41}$ Ibidem.

${ }^{42}$ P. Żmigrodzki (red.), op. cit., hasło: ewakuacja.
} 
znajdować się stosunkowo niedaleko, co nie zawsze jest wykonalne przy zdarzeniach o dużych skutkach, bądź zdarzeniach z czynnikiem chemicznym, biologicznym czy fizycznym. Widać w tym miejscu konieczność logistycznego zabezpieczenia ewakuacji. Uwagę przykuwa również nieuwzględnienie $\mathrm{w}$ procesie ewakuacji mienia, które - choć nie najcenniejsze - również jest nierzadko warte ewakuowania. W drugim zaś podanym znaczeniu ewakuacją jest „szybkie opuszczenie jakiegoś miejsca, w którym nie chce się przebywać" ${ }^{43}$. Tym samym podkreślono ważkość kluczowego parametru czasu trwania ewakuacji, lecz zarazem nie zaakcentowano istotności (choćby potencjalnego) czynnika zagrożenia, co można jednak uzasadnić stosowaniem tego pojęcia w języku potocznym, o czym wspominano już wcześniej.

Mając na względzie powyższe licznie przytoczone ujęcia definicyjne, do których udało się dotrzeć autorowi, można zgłosić do nich szereg zastrzeżeń, co tym samym wskazuje na jedynie częściowe obejmowanie przez nie natury całego zjawiska ewakuacji traktowanej w ujęciu szerokim. Ustalenia te pozostaje skonfrontować także z kolejnymi źródłami, tym razem innymi aniżeli słowniki języka polskiego czy wyrazów obcych. Będzie to stanowiło dalszy krok w dociekaniach autora i poszukiwaniach przez niego wskazówek celem zaproponowania własnej definicji ewakuacji właściwej naukom o bezpieczeństwie, o ile do takowej nie uda mu się uprzednio dotrzeć.

\section{Podsumowanie}

Pojęcie ewakuacji w myśl słowników języka polskiego oraz słowników wyrazów obcych jest pojęciem o wielu znaczeniach. Jest ono w powszechnym użyciu - będąc wykorzystywane zarówno w codziennym życiu (w szczególności w potocznym znaczeniu), ale również w licznych wyspecjalizowanych dziedzinach aktywności i życia człowieka. Rodowodu ewakuacji należy doszukiwać się w łacinie, skąd można wysnuć dość prawdopodobne przesłanki sugerujące kojarzenie analizowanego terminu z opróżnieniem (opróżnianiem), zniknięciem (znikaniem), pustką - co zdaje się, jest nadal pośrednio odzwierciedlane we współczesnych jego znaczeniach.

Rozumienie ewakuacji w ujęciu szerokim właściwym naukom o bezpieczeństwie zostanie przedstawione także w kolejnej części rozważań autora, z uwzględnieniem zarówno zawartych w niniejszym opracowaniu artykułowym ustaleń, jak i dalszych poczynionych na bazie źródeł prezentujących nierzadko specjalistyczne ujęcia - przepisów prawa i innych regulacji, norm technicznych, literatury fachowej itd. Już teraz należy wskazać, że przytoczone definicje sugerują konieczność uwzględnienia $\mathrm{w}$ ramach procesów ewakuacji parametrów odnoszących się do czasu, miejsc, podmiotu(ów) ewakuowanych i ewakuujących. Tym samym, przystępując do przeprowadzania ewakuacji należy odpowiedzieć na szereg pytań: kiedy, skąd, dokąd, kogo i/lub co, kim i/lub czym oraz jak należy ewakuować? Pojawiają się tym samym liczne ograniczenia warunkowane czasem czy też dostępnymi do wykorzystania w tym celu zasobami ludzkimi, rzeczowymi, finansowymi, informacyjnymi itd. Podejmowane działania ewakuacyjne

\footnotetext{
${ }^{43}$ Ibidem.
} 
są przy tym zasadniczo obciążone czynnikiem stresu, strachu, lęku, paniki, co nie sprzyja w utrzymywaniu wysokich wskaźników prakseologicznych realizowanych działań.

\section{BIBLIOGRAFIA}

Bańko Mirosław (red.). 2005. Wielki słownik wyrazów obcych PWN. Warszawa: Wydawnictwo Naukowe PWN.

Brückner Aleksander. 1985. Słownik etymologiczny języka polskiego. Warszawa: Państwowe Wydawnictwo „Wiedza Powszechna”.

Caba Agnieszka et al. 2008. Wielki słownik wyrazów obcych. Kraków: Krakowskie Wydawnictwo Naukowe.

Doroszewski Witold (red.). 1960. Słownik języka polskiego. Tom 2. D-G. Warszawa: Państwowe Wydawnictwo „Wiedza Powszechna”.

Dubisz Stanisław (red.). 2003. Uniwersalny słownik języka polskiego. Tom 1. A-J. Warszawa: Wydawnictwo Naukowe PWN.

Dunaj Bogusław (red.). 1996. Słownik współczesnego języka polskiego. Warszawa: Wydawnictwo Wilga.

Gruszczyński Włodzimierz (red.). 1954-. Elektroniczny słownik języka polskiego XVII i XVIII wieku. Warszawa: Instytut Języka Polskiego PAN. Pracownia Historii Języka Polskiego XVII i XVIII wieku. Dostępny w Internecie: http://sxvii.pl.

Kamińska-Szmaj Irena (red.). 2001. Słownik wyrazów obcych. Wrocław: Wydawnictwo Europa.

Karłowicz Jan, Kryński Adam, Niedźwiedzki Władysław (red.). 1900. Słownik języka polskiego. Tom 1. A-G. Warszawa: nakładem prenumeratorów.

Kolmann Piotr. 2020. Z problematyki ochrony ludności. Istota ewakuacji w ujęciu specjalistycznym, Warszawa: kps dostępny u autora. Artykuł złożony do kolejnego numeru czasopisma „De Securitate et Defensione. O Bezpieczeństwie i Obronności”.

Kopaliński Władysław (red.). 1967. Słownik wyrazów obcych i zwrotów obcojęzycznych. Warszawa: „Wiedza Powszechna”.

Lam Stanisław (red.). 1939. Trzaski, Everta i Michalskiego. Encyklopedyczny słownik wyrazów obcych. Pochodzenie wyrazów, wymowa, objaśnienia pojęć, skróty, przysłowia cytaty. Warszawa: Księgarnia Wydawnicza Trzaska, Evert i Michalski.

Linde Samuel Bogumił. 1854. Słownik języka polskiego. Tom 1. A-F. Lwów: Zakład Narodowy im. Ossolińskich.

Lubieński Władysław Aleksander. 1763. Historya Polska. Z opisaniem Rządu i Urzędów Polskich. Wilno: Drukarnia J.K.M. Akademicka Societatis Jesu.

Markowski Andrzej, Pawelec Radosław. 2001. Wielki słownik wyrazów obcych i trudnych. Warszawa: Wydawnictwo Wilga.

Rysiewicz Zygmunt (red.). 1961. Słownik wyrazów obcych. 17.000 wyrazów. Warszawa: Państwowy Instytut Wydawniczy.

Ułaszyn Henryk (cz. oprac.). 1937. M. Arcta. Słownik wyrazów obcych. 33.000 wyrazów, wyrażeń i przysłów cudzoziemskich. Warszawa: Wydawnictwo M. Arcta w Warszawie. 
Zdanowicz Aleksander et al. 1861. Słownik języka polskiego. Tom 1. A-O. Wilno: wydany staraniem i kosztem Maurycego Orgelbranda.

Żmigrodzki Piotr (red.). 2007. Wielki słownik języka polskiego. Kraków: Instytut Języka Polskiego PAN. http://www.wsjp.pl. 